\title{
Intravascular Palpography for High-Risk Vulnerable Plaque Assessment
}

\author{
Johannes A. Schaar ${ }^{1,2}$, Chris L. de Korte ${ }^{1,2}$, Frits Mastik ${ }^{1}$, Radj Baldewsing ${ }^{1}$, Evelyn Regar ${ }^{1}$, Pim \\ de Feyter ${ }^{1}$, Cornelis J. Slager ${ }^{1}$, Anton F.W. van der Steen ${ }^{1,2}$, Patrick W. Serruys ${ }^{1}$
}

Background: The composition of an atherosclerotic plaque is considered more important than the degree of stenosis. An unstable lesion may rupture and cause an acute thrombotic reaction. Most of these lesions contain a large lipid pool covered by an inflamed thin fibrous cap. The stress in the cap increases with decreasing cap thickness and increasing macrophage infiltration. Intravascular ultrasound (IVUS) palpography might be an ideal technique to assess the mechanical properties of high-risk plaques.

Technique: Palpography assesses the local mechanical properties of tissue using its deformation caused by the intraluminal pressure.

In Vitro Validation: The technique was validated in vitro using diseased human coronary and femoral arteries. Especially between fibrous and fatty tissue, a highly significant difference in strain ( $p=0.0012$ ) was found. Additionally, the predictive value to identify the vulnerable plaque was investigated. A high-strain region at the lumen-vessel wall boundary has an
$88 \%$ sensitivity and $89 \%$ specificity for identifying such plaques.

In Vivo Validation: In vivo, the technique was validated in an atherosclerotic Yucatan minipig animal model. This study also revealed higher strain values in fatty than fibrous plaques ( $p<$ o.001). The presence of a high-strain region at the lumenplaque interface has a high predictive value to identify macrophages.

Patient Studies: Patient studies revealed high-strain values $(1-2 \%)$ in thin-cap fibrous atheroma. Calcified material showed low strain values (0-0.2\%). With the development of three-dimensional (3-D) palpography, identification of highstrain spots over the full length of a coronary artery becomes available.

Conclusion: Intravascular palpography is a unique tool to assess lesion composition and vulnerability. The development of $3-D$ palpography provides a technique that may develop into a clinical tool to identify the high-risk plaque.

Key Words: Palpography · Vulnerable plaque · Strain · Thin cap · Fibroatheroma

Herz 2003;28:488-95

DOI 10.1007/s00059-003-2488-6

\section{Intravaskuläre Palpographie zur Erfassung vulnerabler Hochrisikoplaques}

Hintergrund: Die Zusammensetzung einer atherosklerotischen Plaque wird als wichtiger erachtet als deren Stenosegrad. Eine instabile Läsion kann aufbrechen und eine thrombotische Reaktion auslösen. Die Mehrzahl dieser Läsionen enthält einen großen lipidreichen Kern, der von einer dünnen entzündeten Kappe bedeckt ist. Der Stress in der Kappe erhöht sich mit abnehmender Dicke der Kappe und zunehmender Makrophageninfiltration. Die intravaskuläre Ultraschall(IVUS-)Palpographie könnte die ideale Technik zur Beurteilung der mechanischen Eigenschaften von Hochrisikoplaques darstellen.
Technik: Die Palpographie erfasst die lokalen mechanischen Eigenschaften von Gewebe mit Hilfe der durch den intravaskulären Druck erzeugten Deformation.

In-vitro-Validierung: Die Methode wurde durch Untersuchung erkrankter Koronar- und Femoralarterien validiert. Insbesondere zwischen fibrösem und fetthaltigem Gewebe ließ sich ein hochsignifikanter Unterschied bezüglich der Gewebsdehnung feststellen $(p=0,0012)$. Zudem wurde der prädiktive Wert für die Diagnose einer vulnerablen Plaque untersucht. Eine Stelle mit hoher Dehnung an der Gefäßoberfläche hat eine Sensitivität von 88\% und eine Spezifität von $89 \%$ für die Erkennung solcher Plaques.

\footnotetext{
${ }^{1}$ Thorax Center, Erasmus Medical Center, Rotterdam,

The Netherlands,

${ }^{2}$ Interuniversity Cardiology Institute of the Netherlands, Utrecht,

The Netherlands.
} 
In-vivo-Validierung: In vivo wurde die Technik in einem atherosklerotischen Yucatan-Minischwein-Modell validiert. Auch diese Untersuchung zeigte höhere Dehnungswerte in fetthaltigen gegenüber fibrösen Plaques $(p<0,001)$. Zudem hat das Vorliegen hoher Dehnungswerte an der Plaqueoberfläche einen hohen prädiktiven Wert für die Erkennung von Makrophagen.

Patientenstudien: Patientenstudien ergaben hohe Dehnungswerte $(1-2 \%)$ in fetthaltigen Plaques mit dünner Kappe. Kalzifiziertes Material zeigte niedrige Dehnungswerte $(0-0,2 \%)$.
Durch die Entwicklung der dreidimensionalen (3-D) Palpographie wird die Identifikation von Stellen mit hohen Dehnungswerten im kompletten Koronarsystem möglich.

Schlussfolgerung: Wie keine andere Methode gestattet die intravaskuläre Palpographie, Zusammensetzung und Vulnerabilität einer Läsion zu beurteilen. Die Entwicklung der 3-D-Palpographie stellt eine Technik zur Verfügung, die sich zu einem klinischen Hilfsmittel zur Identifizierung von Hochrisikoplaques entwickeln könnte.

\section{Schlüsselwörter: Palpographie ·Vulnerable Plaque · Strain · Dünne fibröse Kappe $\cdot$ Fibroatherom}

\section{Introduction}

Identification of the high-risk (vulnerable) plaque is currently one of the major challenges in cardiology. Typical parameters of such plaques are an eccentric plaque with a large atheroma covered by a thin fibrous cap [1, 2]. The presence of macrophages in the cap further increases the vulnerability of the plaques [3]. Although a vast number of techniques are under development, no clinically available technique is able to identify these plaques. All techniques focus on detection of one of the pathologic aspects of the plaques. Using thermography, the heat production of the macrophages may be measured. Optical coherence tomography has a very high resolution and is capable of measuring the thickness of the fibrous cap. Additionally, fibrous and fatty tissue can be discriminated. Near-infraread spectroscopy has a high sensitivity and specificity to identify lipid pools and a moderate sensitivity and high specificity to detect thin caps and inflammation [28]. With Raman spectroscopy, calcium salts and cholesterol can be detected.

The question that remains is: Why does the vulnerable plaque rupture? Therefore, it is not only important to identify the composition and geometry of the plaques but also the response of the tissue to the pulsating force applied by the blood pressure. The plaque is supposed to be prone to rupture, if the cap is unable to withstand the stress applied on it. All the stress that is applied on the plaque by the blood pressure is concentrated in the cap, since the lipid pool is unable to withstand forces on it [4, 5]. As a result, the stress in a thin cap will be higher than the stress in a thicker cap. Furthermore, the strength of the cap is affected by inflammation: fibrous caps with inflammation by macrophages were locally weakened [6]. Therefore, the strength of a cap seems to be a more important parameter than the thickness of the cap.
Intravascular palpography is a technique based on intravascular ultrasound (IVUS). IVUS is currently the only commercially available clinical technique providing real-time cross-sectional images of the coronary artery [7]. Using IVUS, the morphologies of the coronary wall and plaque are obtained. Furthermore, calcified and noncalcified plaque components can be identified. However, the sensitivity to identify fatty plaque components remains low [8,9]. Recent rf(radiofrequency) based tissue identification strategies appear to have better performance $[9,10]$. With palpography, the local strain of the tissue is obtained. This strain is directly related to the mechanical properties. It is known that the mechanical properties of fibrous and fatty plaque components are different [11-13], and therefore palpography has the potential to differentiate between different plaque components. An even more promising feature of palpography is the detection of high-stress regions. Using computer simulations, concentrations of circumferential tensile stress were more frequently found in unstable plaques than in stable ones $[5,14]$. A local increase in circumferential stress in tissue is directly related with an increase of radial strain.

\section{Intravascular Palpography}

Céspedes et al. [15] and Ophir et al. [16] have developed the so-called elastography, an imaging technique which is based on tissue deformation. The rate of deformation (strain) of the tissue is directly related to the mechanical properties. The tissue under inspection is deformed, and the strain between pairs of ultrasound signals with and without deformation is determined [17]. For intravascular purposes, the compression can be obtained from the pressure difference in the artery. Additionally, well-con- 
trolled deformation is possible by using a compliant intravascular balloon [18].

The principle of intravascular elastography is illustrated in Figure 1. An ultrasound image of a human coronary artery is acquired at an intracoronary pressure. After a short time interval, a second acquisition at a slightly lower pressure (approximately $5 \mathrm{mmHg}$ ) is performed. The strain is determined by correlating the signals of the two IVUS echograms. For a detailed description of different methods see de Korte et al. [19]. The elastogram (image of the radial strain) is plotted as a complimentary image to the IVUS echogram. The elastogram reveals the presence of an eccentric region with increased strain values at the shoulders of the eccentric plaque. Since the acting force is applied on the lumen boundaries, a surfacebased assessment of the mechanical properties was developed. This robust technique is easier to interpret and called palpography. Palpography derives mechanical information from the surface of the plaque, where the rupture happens.

\section{Plaque Characterization}

Elastographic experiments were performed in excised human coronary $(\mathrm{n}=4)$ and femoral $(\mathrm{n}=9)$ arteries. Data were acquired at room temperature at intraluminal pressures of 80 and $100 \mathrm{mmHg}$. Coronary arteries were measured using a solid-state $20-\mathrm{MHz}$ array catheter (EndoSonics, Rancho Cordova, CA, USA). Femoral arteries were investigated using a single-element $30-\mathrm{MHz}$ catheter (DuMed/EndoSonics, Rijswijk, The Netherlands). The rf-data was stored and processed off-line. The visualized segments were stained for the presence of collagen, smooth muscle cells (SMC), and macrophages. Matching of elastographic data and histology was performed using the IVUS echogram. The cross-sections were segmented in regions $(n=125)$ based on the strain value on the elastogram. The dominant plaque types in these regions (fibrous, fibrofatty, or fatty) were obtained from histology and correlated with the average strain and echo intensity.

Mean strain values of $0.27 \%, 0.45 \%$ and $0.60 \%$ were found for fibrous, fibrofatty and fatty plaque components. The strain for the three plaque types as determined by histology differed significantly ( $p=$ 0.0002). This difference was independent of the type of artery (coronary or femoral) and was mainly evident between fibrous and fatty tissue $(\mathrm{p}=0.0004)$. The plaque types did not reveal echo-intensity differences in the IVUS echogram $(p=0.992)$. Conversion of the strain into Young's modulus values resulted in $493 \mathrm{kPa}$, $296 \mathrm{kPa}$ and $222 \mathrm{kPa}$ for fibrous, fibrofatty and fatty plaques. Although these values are higher than values measured by Lee et al. [13], the ratio between fibrous and fatty material is similar. Since fibrous and fatty tissue demonstrated a different strain value and highstrain values were often co-localized with increased concentrations of macro-phages, these results reveal the potential of identification of the vulnerable plaque features.

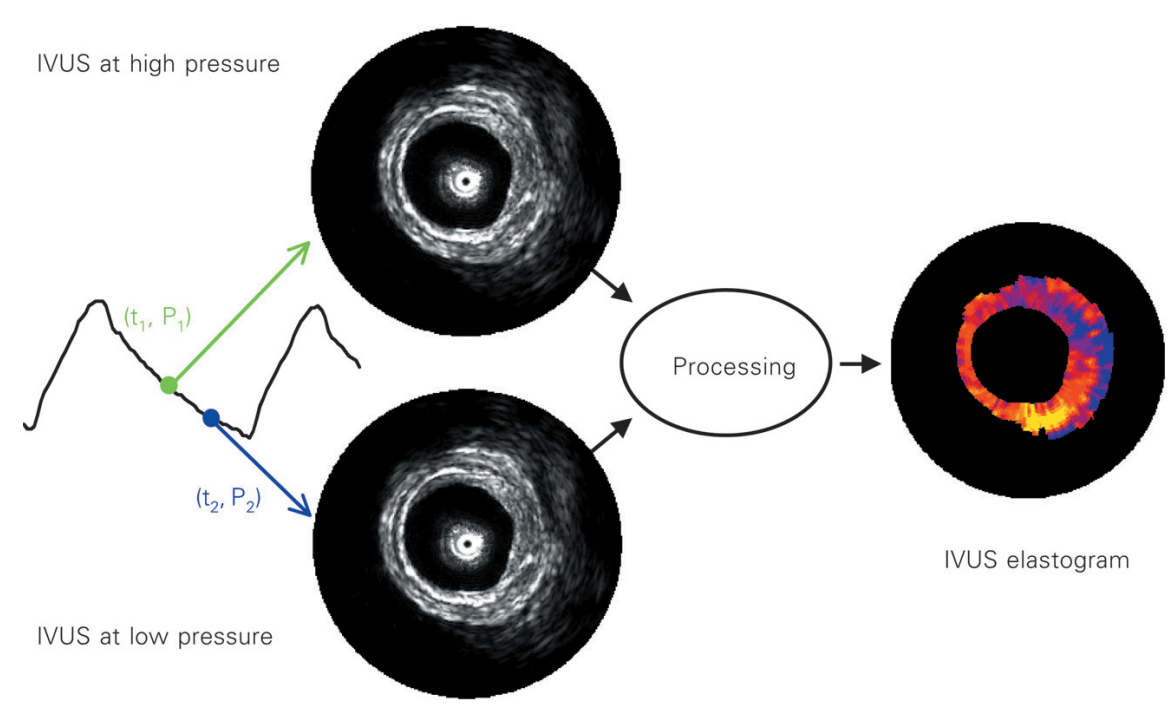

Figure 1. Principle of intravascular elastography measurement procedure: an IVUS echogram is acquired with a low and a high intraluminal pressure. Using cross-correlation analysis on the high-frequency rf-data, the radial strain in the tissue is determined. This information is plotted as an additional image to the IVUS echogram. In this example, an eccentric deformable lesion is visible between 6 and 12 o'clock in the elastogram, whereas this lesion cannot be identified from the IVUS echogram.

Abbildung 1. Das Prinzip der intravaskulären Elastographiemessung: Ein IVUS-Echogramm wird bei niedrigem und hohem intraluminalem Druck aufgezeichnet. Aus diesen Daten werden durch eine Vergleichsanalyse der Hochfrequenz-RF-Daten Informationen zum Dehnungsverhalten gewonnen. Diese Informationen werden neben dem IVUS-Echogramm dargestellt. In diesem Beispiel kann eine exzentrische deformierbare Läsion zwischen 6.00 und 12.00 Uhr im Elastogramm dargestellt werden, während diese Läsion im IVUS-Echogramm nicht sichtbar wäre. 


\section{Vulnerable Plaque Detection}

Although plaque vulnerability is associated with the plaque composition, detection of a lipid or fibrous composition does not directly warrant identification of the vulnerable plaque. Therefore, a study to evaluate the predictive power of elastography to identify the vulnerable plaque was performed.

Diseased coronary arteries $(n=24)$ were measured in vitro. Elastographic data was acquired at intracoronary pressures of 80 and $100 \mathrm{mmHg}$ using a standard IVUS catheter (Jomed, Rancho Cordova, CA, USA). After the ultrasound experiments, the cross-sections were stained for collagen and fat, SMC, and macrophages. Histologically, a vulnerable plaque was defined as a lesion with a large atheroma ( $>40 \%)$, a thin fibrous cap with moderate to heavy infiltration by macrophages. A plaque was considered vulnerable in elastography when a high-strain region was present at the lumen-plaque boundary that was surrounded by low strain values. Using this definition, the instability of the region is assessed.

Figures $2 \mathrm{a}$ to $2 \mathrm{~d}$ show a typical example of a vulnerable elastogram. High-strain regions are present at 6 and 12 o'clock, and these regions are surrounded by low strain values. The regions correspond to the shoulders of this eccentric plaque. Histology reveals a large lipid pool (absence of collagen and SMC) that is covered by a thin fibrous cap. The cap lacks collagen at the shoulder regions. Inflammation by macro-phages is found in the lipid pool and in the cap.

Vulnerable plaques $(\mathrm{n}=23)$ were correctly identified by elastography in 20 cases. Nonvulnerable plaques $(\mathrm{n}=31)$ were detected 27 times but false-positively diagnosed as vulnerable in four cases. This corresponds to a sensitivity and a specificity of $87 \%$ each, a positive predictive value of $83 \%$, and a negative predictive value of $90 \%$ [20].

\section{In Vivo Validation}

IVUS elastography was validated in vivo using an atherosclerotic Yucatan minipig animal model [21, 22]. External iliac and femoral arteries were made atherosclerotic by endothelial Fogarty denudation and subsequent atherosclerotic diet for the duration of 7 months. Balloon dilatation was performed in the femoral arteries, and the diet was discontinued. Before termination, 6 weeks after balloon dilatation and discontinuation of the diet, data were acquired in the external iliac and femoral artery in six Yucatan pigs. In total, 20 cross-sections were investigated with a 20-MHz Visions ${ }^{\circledR}$ catheter (Jomed). The tissue was strained by the pulsatile blood pressure. Two frames acquired at end-diastole with a pressure differential of approximately $4 \mathrm{mmHg}$ were taken to determine the elastograms. 
After the ultrasound experiments and before dissection, X-ray was used to identify the arterial segments that had been investigated by ultrasound. The specimens were frozen in liquid nitrogen. The crosssections $(7 \mu \mathrm{m})$ were stained for collagen (picro Sirius red and polarized light) and macrophages (alkaline phosphatase). Plaques were classified as absent, as early fibrous lesion, as early fatty lesion, or as advanced fibrous plaque. The mean strain in these plaques and normal cross-sections was determined to assess the tissue characterization properties of the technique. Furthermore, the instabil-
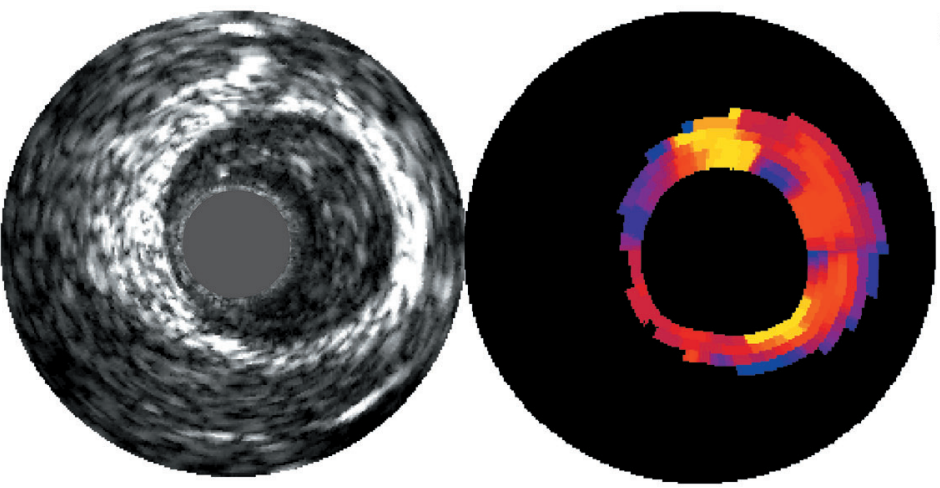

Strain [\%]

2.0

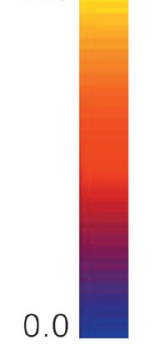

Figure 3. In vivo intravascular echogram and elastogram of a human coronary artery. The elastogram reveals that the plaque has deformable edges with nondeformable surrounding tissue.

Abbildung 3. Intravaskuläres Echogramm und Elastogramm einer Koronararterie in vivo. Das Elastogram zeigt, dass die Plaque deformierbare Enden aufweist, die von nichtdeformierbarem Gewebe umgeben sind. ity of the elastogram was correlated with the presence of fat and macrophages. The instability was characterized by the presence of a high-strain region (strain $>1 \%$ ) at the lumen-vessel wall boundary.

Strains were similar in the plaque-free arterial wall and the early and advanced fibrous plaques. Univariate analysis of variance revealed significantly higher strain values in cross-sections with early fatty lesions than in fibrous plaques $(p=0.02)$ independently of the presence of macrophages. Although a higher strain value was found in plaques with macrophages than in plaques without macrophages, this difference was not significant after correction for fatty components. However, the presence of a high-strain region had a high sensitivity ( $92 \%)$ and specificity (92\%) to identify the presence of macrophages. Therefore, it was concluded that the tissue type dominates the mean strain value. Localized high strain values are related to local phenomena like inflammation.

\section{Patient Studies}

Preliminary acquisitions were performed in patients during percutaneous transluminal coronary angioplasty (PTCA) procedures [23, 24]. Data were acquired in patients $(\mathrm{n}=12)$ with an EndoSonics InVision echoapparatus equipped with an rf-output. For obtaining the rf-data, the machine was working in ChromaFlo mode resulting in images of 64 angles with unfocused ultrasound data. The systemic pressure was used to strain the tissue. This strain was determined using cross-correlation analysis of sequential frames. A likelihood function was determined to obtain the frames with minimal motion of the catheter in the lumen, since motion of the catheter prevents reliable strain estimation. Minimal motion was observed near end-diastole. Reproducible strain estimates were obtained within one pressure cycle and over several pressure cycles. Validation of the results was limited to the information provided by the echogram. Strain in calcified material $(0.20 \%)$ was lower $(p<0.001)$ than in noncalcified tissue $(0.51 \%)$.

High-resolution elastograms were acquired using an EndoSonics InVision echoapparatus [25]. The beamformed image mode (512 angles) ultrasound data ( $\mathrm{fc}=$ $20 \mathrm{MHz}$ ) was acquired with a PC-based acquisition system. Frames acquired at end-diastole with a pressure difference of approximately $5 \mathrm{mmHg}$ were taken to determine the elastograms.

The elastogram of a patient with unstable angina pectoris reveals high strain values in the plaque with very high strain values (up to $2 \%$ ) at the shoulders of this plaque (Figure 3). The same geometry and strain distribution were also found in the in vitro studies. The corresponding histology revealed, in that study, a plaque with a large lipid core covered from the blood by a thin cap. This cap had a lack of collagen at the shoulders and increased inflammation by macrophages. Calcified material, as identified from the echogram, shows strain values of $0-0.2 \%$.

\section{Three-Dimensional Palpography}

In the previous studies, elastograms revealed information of one cross-section. However, the distribution of the strain in the three-dimensional (3-D) geometry of 
an artery is an important tool to identify the presence of high-strain spots, their amount and distribution. Especially, since the correlation between plaque vulnerability and parameters provided by the echogram is low $[8$, 9] selection of cross-sections based on the IVUS echogram introduces selection bias and increases the chance to miss the vulnerable spot. Additionally, during longitudinal monitoring of patients it is extremely difficult to refind the same spot after some months. Therefore, it would be a big step forward to have strain information of the full 3-D coronary artery. Since the rupture of a plaque happens in the superficial area of the plaque, the elastic information of the surface is displayed as palpogram.

In palpography, out-of-plane motion is considered one of the main sources for decorrelation (= lack of correlation) of the signals, thus decreasing the quality of the strain estimate [26, 27]. Therefore, for palpographic acquisitions, the position of the transducer is kept as stable as possible, and only motion in the direction of the beam is allowed [16]. As a consequence, it is unlikely that valid intravascular strain palpograms can be obtained while performing a continuous pullback of the catheter. However, if the pullback speed is only $1 \mathrm{~mm} / \mathrm{s}$ and the strain is determined using two subsequent frames, the motion introduced by the pullback is minimal. Furthermore, it is known that due to the contraction of the heart, in diastole the catheter will move distally in the coronary if the catheter is kept in a steady position. Therefore, performing a pullback will decrease out-of-plane motion in this phase of the heart cycle. Since elastography uses data acquired in the diastolic phase, performing a pullback and thus obtaining 3-D data seems feasible.

Preliminary experiments in rabbit aortas reveal that 3-D palpography is feasible in vivo. Despite the introduction of out-of-plane motion by the continuous pullback of the catheter, the similarity between successive frames acquired in the diastolic phase is high enough to calculate several palpograms per heart cycle. By combining these palpograms, one compound palpogram per heart cycle is determined [29]. Strain measurements give an indication of the mechanical properties of the plaque, without taking the shear forces into account, which may be responsible for activation of biological processes inducing instabilities. Assessment of shear stress is feasible by obtaining high-resolution reconstruction of 3-D coronary lumen and wall morphology using the combination of angiography and IVUS [32].
Briefly, a biplanar angiogram of a sheath-based IVUS catheter taken at end-diastole allows reconstruction of the 3-D pullback trajectory of the catheter. Combining this path with lumen and wall information derived from IVUS images, that are successively acquired during catheter pullback at end-diastole, gives accurate 3-D lumen and wall reconstruction with resolution determined by IVUS. Filling the 3-D lumen space with a highresolution 3-D mesh allows calculation of the detailed blood velocity profile in the lumen [33]. For this purpose, absolute flow and blood viscosity need to be provided as boundary conditions. From the blood velocity profile, local wall shear stress on the endothelium can be accurately derived. Wall shear stress is the frictional force, normalized to surface area, that is induced by the blood passing the wall. Although from a mechanical point of view shear stress is of a very small magnitude compared to blood pressure-induced tensile stress, it has a profound influence on vascular biology [34] and explains the localization of atherosclerotic plaque in the presence of systemic risk factors [35]. Many of these biological processes also influence the stability of the vulnerable plaque including inflammation, thrombogenicity, vessel remodeling, intimal thickening or regression, and SMC proliferation. Therefore, the assessment of shear stress in combination with strain measurements is of utmost importance.

\section{Discussion}

Identification of plaque components and the proneness of a lesion to rupture is a major issue in interventional cardiology. IVUS echography is a real-time, clinically available technique capable of providing cross-sectional images and identifying calcified plaque components. Since palpography only requires ultrasound data sets that are acquired at different levels of intraluminal pressure, it can be realized using conventional catheters. It has been shown that palpograms can be produced in vitro and in vivo.

The question still not answered is the relevance of the information given by the palpogram. A palpogram is an image of the strain and, therefore, a representation of Young's modulus. This artifactual presentation can be observed in Figures 2a to 2d. Although the plaque contains a large lipid core, the elastogram does not reveal high-strain values in the core of the plaque. This is caused by the geometry of this plaque. The fibrous cap is protecting the lipid pool from large deformation. However, at the shoulder regions a larger strain than expected is ob- 
served. This example indicates that the strain cannot always be directly translated into a Young's modulus. However, using finite element analysis, an image of the Young's modulus can be reconstructed using the strain and/or displacement information (also known as solving the inverse problem) [30,31]. Analysis of these complex geometries has to be performed to identify the differences between and the similarities of strain and modulus images. Currently, the inverse problem is being solved for strain images acquired from human artery specimen in vitro. The resulting Young's modulus images and the strain images will be related to the histology.

Identification of vulnerable plaques is of paramount importance to investigate the underlying principle of plaque rupture, the effectiveness of pharmaceutical treatments, and the influence on the long-term prevention of sudden cardiac deaths. For detection of these vulnerable plaques, a Young's modulus image does not seem necessary. The presence of a high-strain spot that is surrounded by low strain has a high predictive power to identify the rupture-prone plaque in vitro with high sensitivity and specificity. Since there is currently no clinically available technique capable of identifying the rupture-prone plaque, IVUS palpography may be one of the first techniques that can be applied in patients to assess the vulnerability of plaques. With the development of 3-D palpography, identification of weak spots over the full length of a coronary artery becomes available. A prospective study in patients that correlates clinical events with the distribution of these weak spots is currently being performed and will define the value of palpography as a clinical tool.

\section{Conclusion}

Intravascular palpography is a technique that assesses the local strain of the vessel wall and plaque. Both in vitro and in vivo studies revealed that the strain is higher in fatty than in fibrous plaques. Additionally, the presence of a high-strain region has a high sensitivity and specificity to detect the vulnerable plaque. With the introduction of 3-D palpography, a technique becomes available that may develop into a clinically available tool to identify the rupture-prone plaque.

\section{Acknowledgments}

Supported by The Dutch Technology Foundation (STW) and The Netherlands Organization for Scientific Research (NWO), The Dutch Heart Foundation (NHS), and The German Heart Foundation (DHS)

\section{References}

1. Falk E, Shah P, Fuster V. Coronary plaque disruption. Circulation 1995;92:657-71.

2. Fuster $\mathrm{V}$, Stein B, Ambrose J, et al. Atherosclerotic plaque rupture and thrombosis. Evolving concepts. Circulation 1990;82:1l:47-59.

3. Moreno PR, Falk E, Palacios IF, et al. Macrophage infiltration in acute coronary syndromes: implications for plaque rupture. Circulation 1994;90:775-8.

4. Loree HM, Kamm RD, Stringfellow RG, et al. Effects of fibrous cap thickness on peak circumferential stress in model atherosclerotic vessels. Circ Res 1992;71:850-8.

5. Richardson PD, Davies MJ, Born GVR. Influence of plaque configuration and stress distribution on fissuring of coronary atherosclerotic plaques. Lancet 1989;21:941-4.

6. Lendon CL, Davies MJ, Born GVR, et al. Atherosclerotic plaque caps are locally weakened when macrophage density is increased. Atherosclerosis 1991;87:87-90.

7. Mintz GS, Nissen SE, Anderson WD, et al. ACC clinical expert consensus document on standards for acquisition, measurement and reporting of intravascular ultrasound studies (IVUS). A report of the American College of Cardiology Task Force on Clinical Expert Consensus Documents. J Am Coll Cardiol 2001; 37:1478-92.

8. Prati F, Arbustini E, Labellarte A, et al. Correlation between high frequency intravascular ultrasound and histomorphology in human coronary arteries. Heart 2001;85:567-70.

9. Komiyama N, Berry G, Kolz M, et al. Tissue characterization of atherosclerotic plaques by intravascular ultrasound radiofrequency signal analysis: an in vitro study of human coronary arteries. Am Heart J 2000;140:565-74.

10. Hiro T, Fujii T, Yasumoto K, et al. Detection of fibrous cap in atherosclerotic plaque by intravascular ultrasound by use of color mapping of angle-dependent echo-intensity variation. Circulation 2001;103:1206-11.

11. Loree HM, Tobias BJ, Gibson L, et al. Mechanical properties of model atherosclerotic lesion lipid pools. Arterioscler Thromb 1994;14:230-4.

12. Loree HM, Grodzinsky AJ, Park SY, et al. Static circumferential tangential modulus of human atherosclerotic tissue. J Biomech 1994;27:195-204.

13. Lee RT, Richardson G, Loree HM, et al. Prediction of mechanical properties of human atherosclerotic tissue by high-frequency intravascular ultrasound imaging. Arterioscler Thromb 1992;12:1-5.

14. Cheng GC, Loree HM, Kamm RD, et al. Distribution of circumferential stress in ruptured and stable atherosclerotic lesions. A structural analysis with histopathological correlation. Circulation 1993;87:1179-87.

15. Céspedes El, Ophir J, Ponnekanti H, et al. Elastography: elasticity imaging using ultrasound with application to muscle and breast in vivo. Ultrason Imaging 1993;17:73-88.

16. Ophir J, Céspedes El, Ponnekanti H, et al. Elastography: a method for imaging the elasticity in biological tissues. Ultrason Imaging 1991;13:111-34.

17. Céspedes EI, Huang Y, Ophir J, et al. Methods for estimation of subsample time delays of digitized echo signals. Ultrason Imaging 1995;17:142-71.

18. Sarvazyan AP, Emelianov SY, Skovorada AR. Intracavity ultrasonic device for elasticity imaging. US patent US 5265612, 1993.

19. De Korte CL, van der Steen AFW. Intravascular ultrasound Elastography: an overview. Ultrasonics 2002;40:859-65.

20. Schaar J, de Korte CL, Mastik F, et al. Vulnerable plaque detection with intravascular elastography: a sensitivity and specificity study. Circulation 2001;104:11459. 
21. De Korte CL, Sierevogel M, Mastik F, et al. Intravascular elastography in Yucatan pigs: validation in vivo. Eur Heart J 2001;22:251.

22. De Korte CL, Sierevogel M, Mastik F, et al. Identification of atherosclerotic plaque components with intravascular ultrasound elastography in vivo: a Yucatan pig study. Circulation 2002;105: 1627-30.

23. De Korte CL, Carlier SG, Mastik F, et al. Intracoronary elastography in the catheterisation laboratory: preliminary patient results. In: IEEE Ultrasonics Symposium, Lake Tahoe, CA, USA, 1999:1649-52.

24. De Korte CL, Carlier SG, Mastik F, et al. Morphological and mechanical information of coronary arteries obtained with intravascular elastography: a feasibility study in vivo. Eur Heart J 2002;23:405-13.

25. De Korte CL, Doyley MM, Carlier SG, et al. High resolution IVUS elastography in patients. In: IEEE Ultrasonics Symposium, Puerto Rico, USA, 2000:1767-70.

26. Konofagou E, Ophir J. A new elastographic method for estimation and imaging of lateral displacements, lateral strains, corrected axial strains and Poisson's ratios in tissues. Ultrasound Med Biol 1998;24:1183-99.

27. Kallel F, Ophir J. Three dimensional tissue motion and its effect on image noise in elastography. IEEE Trans UFFC 1997;44: 1286-96.

28. Moreno PR, Muller JE. Detection of high-risk atherosclerotic plaques by intravascular spectroscopy. J Interv Cardiol 2003;16: $243-52$.

29. Doyley M, Mastik F, de Korte CL, et al. Advancing intravascular ultrasonic palpation towards clinical applications. Ultrasound Med Biol 2001;27:1471-80.

30. De Korte CL, Céspedes El, van der Steen AFW, et al. Image artifacts in intravascular elastography. In: IEEE EMBS, Amsterdam, The Netherlands; 1996:paper no. 685.
31. Soualmi L, Bertrand $M$, Mongrain R, et al. Forward and inverse problems in endovascular elastography. In: Lees S, Ferrari LA, eds. Acoustical imaging. New York: Plenum Press, 1997:203-9.

32. Slager, CJ, Wentzel JJ, Schuurbiers JCH et al. True 3-dimensiona reconstruction of coronary arteries in patients by fusion of angiography and IVUS (ANGUS) and its quantitative validation. Circulation 2000;102:511-6.

33. Thury A, Wentzel JJ, Schuurbiers JC, et al. Prominent role of tensile stress in propagation of a dissection after coronary stenting: computational fluid dynamic analysis on true 3d-reconstructed segment. Circulation 2001;104:E53-4.

34. Malek AM, Alper SL, Izumo S. Hemodynamic shear stress and its role in atherosclerosis. JAMA 1999;282:2035-42.

35. Asakura T, Karino T. Flow patterns and spatial distribution of atherosclerotic lesions in human coronary arteries. Circ Res 1990;66:1045-66.

\section{Address for Correspondence}

Johannes A. Schaar, MD

Experimental Echocardiography Ee23.02

Erasmus Medical Center

PO Box 1738

3000 DR Rotterdam

The Netherlands

Phone (+31/10) 408-7305, Fax -9445

e-mail: j.schaar@erasmusmc.nl 